\title{
INTERNALISASI PENDIDIKAN KARAKTER DAN ANTI KORUPSI DALAM MATA PELAJARAN PADA SEKOLAH MENENGAH PERTAMA DI KABUPATEN BOYOLALI
}

\author{
Sri Hastuti, Muhammad Rohmadi, dan Kundharu Saddhono \\ Universitas Sebelas Maret \\ Email: srihastuti@staff.uns.ac.id
}

\begin{abstract}
ABSTRAK
Korupsi merupakan masalah yang tidak pernah selesai di Indonesia hingga saat ini. Masalah korupsi di Indonesia terus menjadi berita utama (headline) hampir setiap hari di media Indonesia dan menimbulkan banyak perdebatan panas dan pembahasan untuk mengatasinya. Di kalangan akademik, para cendekiawan telah secara terus-menerus mencari jawaban atas pertanyaan apakah korupsi ini sudah memiliki akarnya di masyarakat dan perlu treatment khusus untuk mengatasinya. Korupsi sudah merebak di beberapa institusi bahkan dari pejabat daerah sampai pejabat di lembaga tinggi Negara terkena kasus korupsi. Walaupun sudah digencarkan iklan dan semboyan anti korupsi di berbagai media dan kesempatan, akan tetapi hal itu tidak mengurangi praktik korupsi di Indonesia. Ancaman hukuman penjara juga seakan tidak memberikan efek jera pada para pelaku korupsi. Oleh karenanya, diperlukan suatu upaya pemberantasan dan pencegahan korupsi yang harus dilakukan serta didukung oleh semua elemen masyarakat. Penanaman mengenai gerakan anti korupsi akan lebih efektif apabila difokuskan kepada generasi muda sebagai generasi penerus bangsa melalui pendidikan karakter dan internalisasi pendidikan anti korupsi. Hal ini dilakukan dengan cara memberikan penjabaran mengenai bahaya korupsi, apa penyebabnya, bagaimana akibatnya bagi kelangsungan hidup suatu negara, bagaimana upaya untuk mencegah dan memberantas korupsi sejak dini. Oleh karenanya, sasaran dari kegiatan PKM kali ini adalah siswa Sekolah Menengah Pertama (SMP) di Kabupaten Boyolali, khususnya adalah di SMP wilayah Kabupaten Boyolali, Jawa Tengah. Kegiatan PKM ini rencananya dilakukan dalam jangka waktu selama delapan bulan yang terdiri atas tiga tahapan kegiatan. Kegiatan "Internalisasi Pendidikan Karakter dan Anti Korupsi dalam Mata Pelajaran pada Sekolah Menengah Pertama di Kabupaten Boyolali” ini mampu memberikan pemahaman mengenai bahaya korupsi kepada guru dan siswa SMP di Kabupaten Boyolali, sekaligus juga sebagai salah satu upaya mengurangi praktik korupsi sejak dini.
\end{abstract}

Kata kunci: Internalisasi, Pendidikan Antikorupsi, SMP, Boyolali 


\section{PENDAHULUAN}

Di dalam pembahasan pendidikan anti korupsi dimaknai sebagai upaya yang dilakukan untuk meminimalisir dan memberantas korupsi melalui pendidikan. Pendidikan dipilih sebagai salah satu alternatif pemberantasan korupsi karena pendidikan sendiri memiliki dua fungsi esensial, yakni menumbuhkan kreatifitas dan menanamkan serta mensosialisasikan nilai-nilai luhur. Pengertian pendidikan anti korupsi sebagaimana yang sudah di jelaskan sebelumnya bahwa pendidikan anti korupsi merupakan usaha sadar dan terencana untuk mewujudkan proses belajar mengajar yang kritis terhadap nilai-nilai anti korupsi. Dalam proses tersebut, maka pendidikan anti korupsi bukan sekedar media bagi transfer pengalihan pengetahuan (kognitif), namun juga menekankan pada upaya pembentukan karakter (afektif), dan kesadaran moral dalam melakukan perlawanan (psikomotorik), terhadap penyimpangan perilaku korupsi.

Data dari Liputan6.com menyatakan bahwa dalam tiga tahun terakhir jumlah kasus korupsi di Indonesia yakni Data dari penyidikan kasus korupsi dalam empat tahun terakhir pada 2014 ada 56 kasus korupsi yang disidik KPK. Kemudian naik pada 2015 menjadi 57 kasus, dan pada 2016 naik lagi menjadi 99 kasus. Bahkan hingga 30 September 2017 ada 78 penyidikan kasus korupsi yang sedang ditangani. Modus korupsi yang paling sering dilakukan adalah penyuapan. Pada 2014 ada 20 kasus penyuapan, tahun 2015 naik menjadi 38 kasus, dan 2016 naik lagi menjadi 79 kasus penyuapan, dan tahun ini hingga 30 September sudah mencapai 55 kasus penyuapan.

Upaya pemberantasan dan pencegahan korupsi harus menjadi agenda utama bangsa kita ini, semua komponen bangsa harus berperan aktif sesuai dengan kapasitas masing-masing guna membrantas dan mencegah korupsi. Upaya pencegahan korupsi itu sendiri dapat dijadikan sebagai fokus kepada generasi masa depan bangsa ini. Dengan cara memberikan pendidikan pengenalan akan bahaya korupsi, apa penyebabnya, bagaimana akibatnya bagi kelangsungan hidup suatu negara, bagaimana mencegahnya bagi generasi muda adalah hal yang sangat efektif. Sekolah adalah wadah paling utama untuk mengimplementasikan Pendidikan Antikorupsi. Bagi bangsa Indonesia diperlukan dukungan dari seluruh elemen bangsa ini agar dari generasi ke generasi tidak terjerumus ke dalam jurang yang sama. Untuk itu diperlukan tekad yang bulat serta keinginan yang kuat terutama dari pemerintah untuk terus melakukan perbaikan dan penyempurnaan terhadap produk peraturan dan kebijakan yang ada guna mengatasi permasalahan yang berkaitan dengan korupsi di negeri ini. 
Bagi Indonesia sekarang ini, pendidikan karakter juga berarti melakukan usaha sungguhsungguh, sistematik dan berkelanjutan untuk membangkitkan dan menguatkan kesadaran serta keyakinan semua orang Indonesia bahwa tidak akan ada masa depan yang lebih baik tanpa membangun dan menguatkan karakter rakyat Indonesia. Dengan kata lain, tidak ada masa depan yang lebih baik yang bisa diwujudkan tanpa kejujuran, tanpa meningkatkan disiplin diri, tanpa kegigihan, tanpa semangat belajar yang tinggi, tanpa mengembangkan rasa tanggung jawab, tanpa memupuk persatuan di tengah-tengah kebhinekaan, tanpa semangat berkontribusi bagi kemajuan bersama, serta tanpa rasa percaya diri dan optimisme. Terlepas dari persoalan kuantitatif maupun kualitatif tersebut, dalam konteks pembangunan sektor pendidikan, guru merupakan pemegang peran yang amat sentral dalam proses pendidikan. Upaya meningkatkan profesionalisme para pendidik adalah suatu keniscayaan.

Guru harus mendapatkan program-program pelatihan secara tersistem agar tetap memiliki profesionalisme yang tinggi dan siap melakukan adopsi inovasi. Guru juga harus mendapatkan"Reward "(tanda jasa), penghargaan dan kesejahteraan yang layak atas pengabdian dan jasanya, sehingga setiap inovasi dan pembaruan dalam bidang pendidikan dapat diterima dan dijalaninya dengan baik. Di sinilah kemudian karakteristik pendidikan guru memiliki kualitas ketika menyajikan bahan pengajaran kepada subjek didik. Kualitas seorang guru dapat diukur dari segi moralitas, bijaksana, sabar dan menguasai bahan pelajaran ketika beradaptasi dengan subjek didik. Sejumlah faktor itu membuat dirinya mampu menghadapi masalahmasalah sulit, tidak mudah frustasi, depresi atau stress secara positif, dan tidak destruktif.

Dalam karakter pendidikan guru penting sekali dikembangkan nilai-nilai etika dan estetika inti seperti kepedulian, kejujuran, keadilan, tanggung jawab, dan rasa hormat terhadap diri dan orang lain bersama dengan nilai-nilai kinerja pendukungnya seperti ketekunan, etos kerja yang tinggi, dan kegigihan sebagai basis karakter yang baik. Guru harus berkomitmen untuk mengembangkan karakter peserta didik berdasarkan nilainilai yang dimaksud serta mendefinisikannya dalam bentuk perilaku yang dapat diamati dalam kehidupan sekolah sehari-hari (Saddhono, 2014). Yang terpenting adalah semua komponen sekolah bertanggung jawab terhadap standar-standar perilaku yang konsisten sesuai dengan nilai-nilai inti.Seseorang dapat dikatakan berkarakter jika telah berhasil menyerap nilai dan keyakinan yang dikehendaki masyarakat serta digunakan sebagai kekuatan moral dalam hidupnya. Demikian juga seorang pendidik dikatakan berkarakter, jika memiliki nilai dan keyakinan yang dilandasi hakikat dan tujuan pendidikan serta digunakan sebagai kekuatan 
moral dalam menjalankan tugasnya sebagai pendidik. Dengan demikian pendidik yang berkarakter, berarti telah memiliki kepribadian yang ditinjau dari titik tolak etis atau moral, seperti sifat kejujuran, amanah, keteladanan, ataupun sifat-sifat lain yang harus melekat pada diri pendidik. Pendidik yang berkarakter kuat tidak hanya memiliki kemampuan mengajar dalam arti sempit (transfer pengetahuan/ilmu), melainkan juga harus memiliki kemampuan mendidik dalam arti luas (keteladanan sehari-hari).

Pendidikan karakter perlu dikembangkan di sekolah. Sebagai upaya untuk meningkatkan kesesuaian dan mutu pendidikan karakter, Kementerian Pendidikan dan Kebudayaan mengembangkan grand design pendidikan karakter untuk setiap jalur, jenjang, dan jenis satuan pendidikan. Grand design menjadi rujukan konseptual dan operasional pengembangan, pelaksanaan, dan penilaian pada setiap jalur dan jenjang pendidikan. Pengembangan pendidikan karakter bisa menggunakan kurikulum berkarakter atau "Kurikulum Holistik Berbasis Karakter" (Character-based Integrated Curriculum). Kurikulum ini merupakan kurikulum terpadu yang menyentuh semua aspek kebutuhan anak. Sebuah kurikulum yang terkait, tidak terkotak-kotak dan dapat merefleksikan dimensi, keterampilan, dengan menampilkan tematema yang menarik dan kontekstual.Bidang-bidang pengembangan yang ada di TK hingga SMA yang dikembangkan dalam konsep pendidikan kecakapan hidup yang terkait dengan pendidikan personal dan sosial, pengembangan berpikir/kognitif, pengembangan karakter dan pengembangan persepsi motorik juga dapat tersusun dengan baik apabila materi ajarnya dirancang melalui pembelajaran yang terpadu dan menyeluruh (Holistik). Pembelajaran holistik terjadi apabila kurikulum dapat menampilkan tema yang mendorong terjadinya eksplorasi atau kejadian-kejadian secara autentik dan alamiah. Dengan munculnya tema atau kejadian yang alami ini akan terjadi suatu proses pembelajaran yang bermakna dan materi yang dirancang akan saling terkait dengan berbagai bidang pengembangan yang ada dalam kurikulum.

Kelompok sasaran program PKM ini adalah Sekolah Menengah Pertama (SMP) di Kabupaten Boyolali, khususnya adalah di SMA Negeri dan SMK Negeri di Kecamatan Banyudono, Kabupaten Boyolali, Jawa Tengah. Pendidikan karakter dewasa ini sudah sering kita dengar di sekolah. Berbagai manfaat akan pendidikan ini juga telah banyak disosialisasikan. Akan tetapi, hal ini kurang lebih masih $80 \%$ hanya bersifat teoretis dan belum bisa teraplikasikan dan terimplementasikan dengan baik. Padahal, landasan fundamental pada setiap kurikulum pendidikan adalah hal-hal yang bertujuan menumbuhkembangkan karakter 
setiap peserta didik. Di sisi lain yang masih berkaitan dengan pendidikan karakter, pendidikan antikorupsi dewasa ini juga menjadi hal yang patut diperhitungkan untuk diterapkan kepada peserta didik, khususnya di Sekolah Menengah Atas. Hal ini dikarenakan pada usia ini, peserta didik sudah mulai masuk ke tahapan mencari jati diri mereka. Maka dari itu, sebelum mendapatkan pengaruh-pengaruh yang negatif, pada pendidikan yang sedang mereka tempuh sudah sepantasnya terdapat pendidikan yang mengarahkan karakter mereka supaya menjadi pribadi yang baik dan berjiwa antikorupsi.

Program PKM ini akan dilaksanakan selama delapan bulan yang terdiri dari tiga tahapan yaitu perencanaan, pelaksanaan, dan evaluasi. Tahap perencanaan dilakukan dengan survei lapangan, menghubungi kepada pihak-pihak terkait, dan menjalin kerjasama kepada beberapa Sekolah Menengah Pertama (SMP) di Kabupaten Boyolali serta mempersiapkan sarana dan prasarana yang mendukung kegiatan ini. Tahap pelaksanaan adalah melakukan pengoordinasian kepada setiap tim pelaksana untuk melaksanakan program-program yang telah direncanakan pada tahap sebelumnya, seperti melakukan observasi dan analisis pada perangkat pembelajaran yang ada di Sekolah Menengah Pertama (SMP) tersebut dan mengundang beberapa pihak dari setiap Sekolah Menengah Pertama (SMP) yang ditunjuk, mengadakan sosialisasi, dan pelatihan terkait aplikasi dan implementasi pendidikan karakter dan antikorupsi yang nantinya diterapkan pada kegiatan pembelajaran di kelas. Tahap monitoring dan evaluasi meliputi kegiatan memantau di setiap Sekolah Menengah Pertama (SMP) yang telah mendapatkan sosialisasi dan pendampingan seperti yang dijelaskan pada tahap pelaksanaan di atas dan mengevaluasi atas apa yang telah dicapai setelah melaksanakan seluruh kegiatan PKM ini.

Pelaksanaan kegiatan berupa sosialisasi dan pelatihan kepada beberapa Sekolah Menengah Pertama (SMP) di Kabupaten Boyolali ini akan berlangsung selama 8 bulan. Tahap awal ialah melakukan survei berkaitan dengan permasalahan yang terkait dengan aplikasi dan implementasi pendidikan karakter dan antikorupsi di setiap kurikulum tingkat satuan pendidikan mereka. Tahap ini bertujuan untuk mendapatkan gambaran realitas atas masalah yang akan ditindaklanjuti. Berikutnya adalah menjalin hubungan birokrasi kepada pihak-pihak terkait yang dapat melancarkan jalannya kegiatan PKM. Selanjutnya adalah menganalisis beberapa kurikulum dari Sekolah Menengah Pertama (SMP) tertentu dan observasi lapangan guna mendapatkan poin-poin yang perlu diberikan solusi untuk memecahkan masalah terkait pendidikan karakter dan antikorupsi. Kemudian adalah mempersiapkan materi dan sarana 
serta prasarana yang mendukung kegiatan selanjutnya, yakni sosialisasi dan pelatihan terkait hal pendidikan karakter dan antikorupsi. Tahap sosialisasi dan pelatihan akan dilaksanakan denga cara mengundang beberapa delegasi yang nantinya akan menjalankan penerapan pendidikan karakter dan antikorupsi di kelas. Tahap ini dilakukan dengan memberikan sosialisasi secara bersama-sama dan secara terperinci yang akan dilakukan oleh tim pelaksana. Berikutnya adalah tahap pemantauan pada beberapa Sekolah Menengah Pertama (SMP) yang telah diberikan sosialisasi dan pelatihan sebelumnya. Setelah mendapatkan hasil, tahap selanjutnya adalah mengevaluasi seluruh kegiatan PKM yang telah terlaksana ini, sejak dari tahap persiapan hingga tahap akhir ini sehingga mendapatkan simpulan realis terkait dengan hal pendidikan karakter dan antikorupsi di kurikulum Sekolah Menengah Pertama (SMP) di Kabupaten Boyolali.

\section{METODE}

Lokasi PKM adalah di Kabupaten Boyolali, Provinsi Jawa Tengah. Kabupaten Boyolali (Bahasa Jawa: Boya-lali, boya berarti tidak, lali berarti lupa, dan secara harafiah: "tidak lupa". Makna kata Boyolali mengandung maksud bahwa para pelaku pemerintahan dalam menjalankan tugas dan wewenangnya selalu waspada, demikian juga rakyat selalu patuh, taat dan penuh kewaspadaan dalam melaksanakan kewajibannya. Kabupaten ini termasuk kawasan Solo Raya. Boyolali terdiri dari 19 wilayah kecamatan yakni Kecamatan Apel, Andong, Banyudono, Boyolali, Cepogo, Juwangi, Karanggede, Kemusu, Klego, Mojosongo, Musuk, Ngemplak, Nogosari, Sambi, Sawit, Selo, Simo, Teras, dan Wonosegoro.

\section{HASIL DAN PEMBAHASAN}

Pelaksanaan PKM ini direncanakan dalam 3 tahap besar yang masing-masing mempunyai bentuk kegiatan yang berbeda. Tahapan tersebut adalah Tahap Persiapan; Tahap persiapan ini berkaitan dengan hal yang perlu dipersiapkan dalam rangka pelaksanaan PKM ini. Persiapan awal yang dilakukan adalah survei awal ke tempat atau lokasi PKM untuk mendapatkan data awal. Setelah mendapatkan data awal baru menyusun rencana kegiatan PKM sesuai dengan kondisi permasalahan yang dihadapi sekolah dalam penerapan pendidikan karakter dan antikorupsi dalam mata pelajaran. Pada tahap ini juga dilakukan perekrutan mahasiswa yang berkompetensi untuk mendampingi untuk melaksanakan PKM ini.

Tahap Pelaksaaan;Tahap pelaksanaan adalah inti dari PKM ini yang akan dilakukan di 
sekolah. Hasil pengumpulan data di sekolah kemudian dianalisis dan diklasifikasikan hal-hal yang dapat dipadukan bahan untuk mengadakan pengembangan pendidikan karakter dan antikorupsi. Berdasarkan hasil analisis tersebut, dibuatlah sebuah pelatihan atau bimbingan untuk guru dan siswa yang berkaitan dengan pengembangan pendidikan karakter dan antikorupsi dalam mata pelajaran di sekolah. Diharapkan dengan pelatihan atau bimbingan ini dapat meningkatkan pengetahuan guru dan siswa dalam pendidikan karakter dan antikorupsi.

Tahap Evaluasi; Tahap evaluasi adalah tahap akhir dari PKM ini yang akan dilakukan oleh dosen dan mahasiswa mengenai penilaian terhadap apa yang telah mahasiswa lakukan sebelum dan sesudah di sekolah serta keikutsertaan guru dan siswa dalam pelatihan dan bimbingan serta pengembangan pendidikan karakter dan antikorupsi.

Pelaksanaan program PKM ini beranggotakan dua dosen Universitas Sebelas Maret Surakarta. Tahap evaluasi yang dilakukan adalah sebagai berikut, pertama yaitu survei ke tempat yang dilakukan bulan kesatu pada minggu pertama, dilanjutkan minggu kedua yaitu menghubungi aparat pemerintahan dan lembaga yang berwenang dan ditargetkan minggu ketiga sudah membuat kesepakatan dengan sekolah setempat mengenai pelaksanaan program PKM. Dua minggu selanjutnya tepatnya minggu terakhir bulan pertama dan minggu pertama pada bulan kedua yaitu mempersiapkan sarana dan prasarana yang diperlukan untuk melaksanakan program-program yang telah ditentukan.

Minggu kedua pada bulan kedua hingga awal minggu bulan kelima melakukan bimbingan dan pelatihan pendidikan karakter dan antikorupsi yang setiap minggu pertama pada awal bulan mulai dari bulan ketiga hingga bulan kelima diadakan evaluasi rutin terhadap pelatihan yang telah dilakukan sehingga setiap bulannya mahasiswa memantau perkembangan guru dan siswa yang sudah diberi bimbingan dan pelatihan, tahap terakhir dari program PKM ini adalah membuat laporan pertanggungjawaban apa yang telah dilaksanakan selama di lapangan.

Pada target luaran PKM ini dapat dipaparkan dalam tiga bagian utama, yaitu indikator capaian produk program PKM, produk kegiatan PKM, dan hasil program PKM. Secara detail target luaran dapat dipaparkan sebagai berikut Indikator capaian produk program PKM ini adalah nilai pendidikan karakter dan antikorupsi dapat tersosialisasikan kepada guru dan siswa, di khususnya di tingkat SMP Kabupaten Boyolali; Guru dan siswa dapat memperoleh pemahaman mengenai pendidikan karakter dan pendidikan antikorupsi; Guru dan siswa dapat mengintegrasikan nilai pendidikan karakter dan pendidikan anti korupsi dalam mata pelajaran 
di sekolah.

Luaran wajib dan luaran tambahan PKM yaitu satu artikel yang dipublikasikan minimal melalui jurnal ber-ISSN yang dapat diakses secara online atau prosiding dari seminar nasional; Publikasi pada media cetak/online/repository UNS; Peningkatan daya saing perekonoman masyarakat dan penerapan ipteks di masyarakat; Buku pedoman mengenai internalisasi pendidikan karakter dan antikorupsi dalam mata pelajaran tingkat SMP, khususnya untuk Sekolah Menengah Pertama di Kabupaten Boyolali (tambahan); Modul atau bahan ajar yang membahas mengenai pendidikan karakter dan antikorupsi (tambahan).

Hasil Program PKM (dicapai oleh Research Group) adalah Program PKM ini dalam jangka panjang akan dilanjutkan dalam rangka memberikan alternatif pendidikan karakter dan pendidikan antikorupsi pada generasi muda dalam ranah pendidikan, khususnya ditujukan untuk guru dan siswa di tingkat Sekolah Menengah Pertama (SMP) di Kabupaten Boyolali, Jawa Tengah.

\section{KESIMPULAN}

Kegiatan Pengabdian kepada masyarakat ini juga tentunya berdampak pada Universitas Sebelas Maret, untuk menunjang tridharma perguruan tinggi, yaitu pengabdian. Dalam tridharma perguruan tinggi salah satu poinnya adalah pengabdian, yang berarti perguruan tinggi memiliki tanggung jawab untuk melakukan kegiatan pengabdian dan pendampingan kepada masyarakat. Kegiatan PKM ini merupakan salah satu bentuk pengabdian yang berkaitan dengan implementasi pendidikan karakter dan nilai antikorupsi untuk generasi muda, terutama di tingkat Sekolah Menengah Pertama (SMP). Kegiatan penelitian dan pengabdian kepada masyarakat ini sekaligus untuk menjawab kebutuhan akan pengetahuan berkaitan dengan pendidikan karakter dan antikorupsi masih diperlukan oleh sekolah secara umum dan ini menjadi salah satu tanggung jawab mahasiswa yang telah mendapatkan ilmunya di bangku kuliah atau di kampus.

\section{DAFTAR PUSTAKA}

Andretta, Susie. 2005. Information Literacy: a Practitioner's Guide. Oxford: Chandos Publishing. Asosiasi Pekerja Informasi Sekolah Indonesia \& International Federation Library Association. 2008. Aplikasi literasi informasi dalam kurikulum nasional (KTSP) : contoh penerapan untuk 
tingkat SD, SMP dan SMA Indonesian Workshop on Information Literacy (Indonesian - WIL). Bogor

Council of Australian University Librarians. 2001. Information Literacy Standards (1st ed.). Canberra: Council of Australian University Librarians

Diao Ai Lien; Agustin Wydia Gunawan; Dora Aruan \& Santi Kusuma. 2007. Tujuh Langkah Knowledge Management. Jakarta:Universitas Atmajaya.

Dworetzky, John. P. 1990. Introduction to Child Development. New York: West Publishing Company.

Ellis, Arthur. (et. al). 1989. Elementary Language Arts Instruction. New Jersey: Prentice Hall.

Faris, Pamela J. 1993. Language Arts as A Process Approach. Madison, Wisconsin: Brown and Benchmark.

Farmer, Lesley S.Jand Henri, James. 2008. Information Literacy Assessment in K-12 Setting. Maryland: Scarecrow Press.

George, Hanna Chaterina. 2013. Literasi Informasi Pperpustakaan Sekolah: Studi Kasus Penerapan Program Literasi Informasi di Perpustakaan Sekolah Santa Angela, Bandung. Bandung: Universitas Padjadjaran

Godwin, Peter dan Jo Parker (Eds.). 2008. Information Literacy Meets Library 2.0. London : Facet Publishing.

Hasanuddin WS A. Chaedar Alwasilah (Eds). 2009. Ensiklopedi Kebahasaan Indonesia (Jilid II FK). Bandung: Penerbit Angkasa.

Jalongo, Mary Renck. 1992. Early Childhood Language Arts. Boston: Allyn and Bacon.

Latuputty, Hanna, and Dede Mulkan. 2012. Developing a Media and Information Literacy Program: a MIL Program Guide for Teachers and Librarians on Elementary School in Indonesia. Paper disajikan pada The 15th Consal Meeting and General Conference. 29-31 Mei 2012

Laxman, Putu Pendit, Hanna C George \& Lucya Dhamayanti 2013. Information Literacy in Indonesia: The View from the Field. Presentasi pada International Association of School Librarianship The 42nd Annual International Conference incorporating 17th International Forum on Research in School Librarianship. Unpublished.

Saddhono, Kundharu. 2014. Pembelajaran Keterampilan Berbahasa Indonesia: Teori dan Praktik. Yogyakarta; Graha Ilmu. 
Oebay. 2015. "Baca dan Hitung Anak Indonesia Lemah" dalam Media Indonesia Edisi Kamis, 26 Maret 2015.

Tompkins, Gail E. dan Kenneth Hoskisson. 1991. Language Arts: Content and Teaching Strategies. New York: Max Well Macmillan International Publishing Group.

Wilson, Carolyn; Grizzle, Alton; Tuazon, Ramon; Akyempong, Kwame; Cheung, Chi Kim. 2011. Media and Information Literacy Curriculum for Teachers. Paris: UNESCO

Wools, Blanche. 2006. Development of Concept Models: an Outline for a Workshop at the International Workshop on Information Literacy. Presentasi pada International Workshop on Information Literacy, Kuala Lumpur, Malaysia. 11 Juni 2006 